\title{
THE IMPACT OF THE NOVEL CORONAVIRUS INFECTION COVID-19 ON THE MOTHER-PLACENTA-FETUS SYSTEM
}

Nizyaeva NV, Lomova NA $\bowtie$, Dolgopolova EL, Petrova UL, Karapetyan TE, Shmakov RG, Frankevich VE

Kulakov National Medical Research Center for Obstetrics, Gynecology and Perinatology, Moscow, Russia

Impaired placental development during early pregnancy associated with systemic damage to the vascular endothelium in patients with COVID-19 may result in a number of complications. The study was aimed to reveal histological and immunohistochemical $(\mathrm{IHC})$ features of placental tissue in pregnant women with COVID-19 at different stages of gestation, and to examine the contribution of those to pathogenesis of the disease involving mother-placenta-fetus system. The following two groups of pregnant women were studied: index group of 66 patients with COVID-19, and comparison group of 40 women with no symptoms of viral infection. Macroscopic and microscopic examination, and the $\mathrm{IHC}$ analysis of placental samples were carried out. Clinical and anamnestic characteristics of patients with COVID-19 were analyzed taking into account disease severity, delivery route and perinatal outcome. ICH staining using primary antibody revealed elevated expression of proinflammatory factors (TNF $\alpha$, IL8) and reduced level of anti-inflammatory factors (IL4) in placental structures of patients with moderate and severe COVID-19 $(p<0.05)$. The villous tree rearrangement and the development of subclinical placental insufficiency, which could in some cases be decompensated during labor, resulting in clinical manifestations of acute fetal hypoxia were detected in the placental samples obtained from the index group patients. The obstetrical tactics for mothers with COVID-19 should be decided individually based on the risk factors; continuous cardiotocography should be used during labor. It may be appropriate to conduct IHC analysis of placenta in puerperant women with COVID-19 in order to fine-tune the tactics of neonatal management and to predict possible neonatal complications.

Keywords: pregnancy, placenta, COVID-19, fetus, chronic hypoxia, placental insufficiency, proinflammatory response

Funding: the study was supported by RFBR grant № 20-04-60093.

Acknowlegements: here we would like to thank Sinitsina VA, medical laboratory assistant of the $2^{\text {nd }}$ Anatomical Pathology Department of the Kulakov National Medical Research Center for Obstetrics, Gynecology and Perinatology, and Bugrova AV, senior research scientist of the Laboratory for Proteomics and Metabolomics of Human Reproduction of the Kulakov National Medical Research Center for Obstetrics, Gynecology and Perinatology.

Author contribution: Nizyaeva NV — pathomorphological study and IHC analysis, systematic analysis, manuscript writing; Lomova NA — analysis of clinical data, systematic analysis, manuscript writing; Dolgopolova EL — collection and preparation of biological matrix samples in the red zone, statistical analysis of the results: Petrova UL — collection and preparation of biological matrix samples in the red zone; Karapetyan TE — analysis of clinical data; Shmakov RG — analysis of clinical data in the red zone, systematic analysis, manuscript editing; Frankevich VE — preparation of the study, systematic analysis.

Compliance with ethical standards: all patients submitted the informed consent to participate in the study; the study met the requirements of the Declaration of Helsinki, International Conference on Harmonization (ICF), Good Clinical Practice (GCP), and Federal Law No. 323-FZ "On the Basics of Protecting Citizens' Health in the Russian Federation" of November 21, 2011.

$\square$ Correspondence should be addressed: Natalia A. Lomova Oparina, 4, Moscow, 117997; natasha-lomova@yandex.ru

Received: 14.04.2021 Accepted: 25.04.2021 Published online: 29.04.2021

DOI: $10.24075 /$ brsmu.2021.020

\section{ВЛИЯНИЕ НОВОЙ КОРОНАВИРУСНОЙ ИНФЕКЦИИ СОVID-19 НА СИСТЕМУ «МАТЬ-ПЛАЦЕНТА-ПЛОД»}

\author{
Н.В.Низяева, Н.А.Ломова 凶, Е. Л. Долгополова, У. Л. Петрова, Т. Э. Карапетян, Р. Г. Шмаков, В. Е. Франкевич
}

Национальный медицинский исследовательский центр акушерства, гинекологии и перинатологии имени В. И. Кулакова, Москва, Россия

\begin{abstract}
Нарушение развития плаценты на ранних сроках беременности, ассоциированное с системным поражением эндотелия сосудов при COVID-19, может привести к ряду осложнений. Целью исследования было выявить гистологические и иммуногистохимические (ИГХ) особенности ткани плаценты у беременных женщин с COVID-19 на разных сроках гестации и изучить их роль в патогенетических механизмах болезни в системе «мать-плацента-плод". Исследовали две группы беременных: основную из 66 пациенток с COVID-19 и группу сравнения из 40 женщин без признаков вирусной инфекции. Выполняли макроскопическое, микроскопическое и ИГХ-исследования образцов плацент. Проведен анализ клинико-анамнестических характеристик пациенток с COVID-19 с учетом тяжести течения заболевания, родоразрешения и перинатальных исходов. При ИГХ-окрашивании первичными антителами у пациенток с тяжелым и среднетяжелым течением COVID-19 повышена экспрессия в структурах плаценты провоспалительных факторов (TNFa, IL8) и снижен уровень противовоспалительных (IL4) ( $0<0,05)$. В образцах плацент женщин основной группы детектирована перестройка ворсинчатого дерева с развитием субклинической плацентарной недостаточности, в ряде случаев декомпенсируемой в родах, с развитием клинической картины острой гипоксии плода. У матерей с COVID-19 следует выбирать акушерскую тактику индивидуально с учетом факторов риска и проведением в родах непрерывной кардиотокограсии. Целесообразно проводить ИГХ-исследование плаценты родильниц с COVID-19 для уточнения тактики ведения новорожденного и прогноза возможных неонатальных осложнений.
\end{abstract}

Ключевые слова: беременность, плацента, COVID-19, плод, хроническая гипоксия, плацентарная недостаточность, провоспалительный ответ

Финансирование: работа выполнена при финансовой поддержке РФФИ грант рег. № 20-04-60093.

Благодарности: фельдшеру-лаборанту 2-го патологоанатомического отделения НМИЦ АГП им. В. И. Кулакова В. А. Синицыной; с. н. с. лаборатории протеомики и метаболомики репродукции человека НМИЦ АГП им. В. И. Кулакова А. В. Бугровой.

Вклад авторов: Н. В. Низяева - проведение патоморфологического и ИГХ-исследований, систематический анализ, написание рукописи; Н. А. Ломова анализ клинических данных, систематический анализ, написание рукописи; Е. Л. Долгополова - сбор и подготовка биологических сред в условиях «красной зоны», статистический анализ результатов; У. Л. Петрова - сбор и подготовка биологических сред в условиях «красной зоны»; Т. Э. Карапетян анализ клинических данных; Р. Г. Шмаков - анализ клинических данных в условиях «красной зоны», систематический анализ, редактирование рукописи; В. Е. Франкевич - подготовка исследования, систематический анализ.

Соблюдение этических стандартов: все пациентки подписали добровольное инсормированное согласие на участие в исследовании; исследование соответствовало требованиям Хельсинкской декларации, Международной конфееренции по гармонизации (ICF), Стандартов надлежащей клинической практики (GCP), ФЗ «Об основах охраны здоровья граждан в Российской Федерации» № 323-ФЗ от 21 ноября 2011 г.

$\square$ Для корреспонденции: Наталья Анатольевна Ломова ул. Академика Опарина, д. 4, г. Москва, 117997; natasha-lomova@yandex.ru

Статья получена: 14.04.2021 Статья принята к печати: 25.04.2021 Опубликована онлайн: 29.04.2021

DOI: 10.24075/vrgmu.2021.020 
Researchers from all over the world are actively exploring SARS-CoV-2 virus and related COVID-19 disease. These studies are of particular importance for the cohort of pregnant women because of the urgency of the challenge; new information about COVID-19 may contribute to the future health of the next generation. To date, there are no reliable reports of increased obstetric disorder prevalence, as well as of possible perinatal SARS-CoV-2 transmission. Possible correlation between COVID-19 in pregnant/puerperant women and the development of fetal distress syndrome, as well as with thrombocytopenia and liver dysfunction in newborns has been shown [1, 2]. According to researchers from Zurich, COVID-19 causes systemic inflammation of lung vasculature (vasculitis) affecting multiple organs and systems; this has no apparent connection with pneumonia. Inflammation involves endothelium, the internal lining of various organs' blood vessels [3]. Impaired placenta development during early pregnancy associated with systemic endothelial damage in patients with COVID-19 may result in oxidative stress in the placenta, and in a number of complications [4, 5]. Literature analysis shows that systemic inflammatory response syndrome (SIRS) in pregnant women with COVID-19 involves multiple pathogenetic mechanisms resulting in inflammation activation and immune response alteration. Understanding of SIRS pathophysiologal mechanisms involved in mother-placenta-fetus system in patients with COVID-19 promotes improvement of diagnostic methods and deciding pathogenetically based treatment for a number of obstetric complications [5, 6].

The study was aimed to reveal histological and immunohistochemical $(\mathrm{IHC})$ features of placental tissue in pregnant women with COVID-19 at different stages of gestation, and to examine the contribution of these abnormalities to pathogenesis of the disease involving mother-placenta-fetus system.

\section{METHODS}

From March to May 2020 in the 1st Infectious Diseases Department of the National Medical Research Center for Obstetrics, Gynecology and Perinatology named after Academician V. I. Kulakov the "red zone" was established for examination and treatment of patients with COVID-19, among them of pregnant women. A total of 190 beds for patients with COVID-19 and 60 beds for obstetric patients were prepared. Biological material samples (maternal venous blood, cord blood, amniotic fluid, placental tissue) were deposited in the certified biobank of the Center. The index group included pregnant women with verified COVID-19 diagnosis. The average age of the patients was $30.3 \pm 6.25$ years. The patients were enrolled once they were admitted. In order to attain the envisaged goals, clinical and laboratory investigation was performed, and pregnancy management was provided in 66 women with COVID-19 (placental tissue was assessed in 42 cases that ended in delivery, and in one fatal case), and 40 pregnant women of comparison group with no clinical manifestations and laboratory signs of viral infection.

Inclusion criteria: group I - COVID-19 confirmed by PCR test; group II - no COVID-19 based on physical examination data and PCR test. Exclusion criteria: multiple pregnancy.

Macroscopic and microscopic examination was carried out of 42 placental tissue samples obtained from puerperant women with COVID-19, and one dead patient, as well as of 40 placental tissue samples obtained from healthy puerperant women of the comparison group. Paraffin-embedded placental tissue blocks taken from women with uncomplicated pregnancy who delivered in 2017-2018 were used as additional comparison group and to exclude the suppressed disease. Histological assessment (hematoxylin and eosin staining) and $\mathrm{IHC}$ analysis of serial sections were performed. $\mathrm{ICH}$ analysis of $10 \%$ formaline $(\mathrm{pH} 7.4)$ fixed $4-\mu \mathrm{m}$ paraffin sections was carried out using Ventana immunostainer (Roche; UK) with closed detection kit. The automated staining protocol included all stages of standard IHC staining. Ultra View Universal DAB Detection Kit (Ventana Medical Systems, Inc.; USA) was used for visualization. Primary monoclonal SARS-CoV-2 nucleoprotein antibody (N-protein (NP), clon 1518 (1:1000); Bialexa, Russia) was used for detection of viral particles. The control of NP antibody to SARS-CoV-2 expression assessment was the most important issue. Antibodies to SARS-CoV-2 were previously checked by immunoblotting techniques with the use of recombinant protein. Morphometry was used to evaluate the degree of the villous tree syncytiotrophoblast membrane damage. Assessment was carried out with NIS-Element AR3 image analysis system (Nikon; Czech Republic) for Nikon ECLIPSE 80i microscope. Statistical data processing was performed using the SPSS Statistics ver. 21 software package for Windows.

\section{RESULTS}

Analysis of COVID-19 patients' anamnestic and clinical characteristics yielded the following results: the average age of the patients was $30.3 \pm 6.25$ years, the average BMI value was $27.1 \pm 4.6 \mathrm{~kg} / \mathrm{m}^{2}$, the average duration of the disease was 17.6 (6-34) days, and the length of hospital stay was 14.9 (4-30) days. Negative PCR test confirming the absence of SARSCoV-2 virus in the oropharyngeal mucosa was obtained within 15.6 (6-31) days (on average). The major clinical manifestations observed in patients were as follows: loss of smell (34.9\%), hyperthermia (33.3\%), and cough (51.5\%). Asymptomatic COVID-19 was observed in 15 patients (22.7\%). Patients with mild, moderate and severe disease accounted for 25 (38\%), 20 (30.2\%) and 6 (9.1\%) cases respectively.

All pregnant women received low molecular weight heparin and interferon alpha-2b. Antimicrobial therapy included amoxicillin-clavulanic acid combination (46\%) and macrolides (28\%). Carbapenems were considered as the drug of choice in severe cases. Supplemental oxygen was required in six cases $(9 \%)$, of those in four cases $(6 \%)$ it was used in the intensive care unit, and in two cases (3\%) it was used during artificial ventilation. Corticosteroids (dexamethasone $12 \mathrm{mg} /$ day for 3-4 days) and immunoglobulin therapy ( $0.5 \mathrm{~g} / \mathrm{kg}$ for $3-4$ days) were also prescribed. One maternal death from pulmonary embolism and multiple organ dysfunction syndrome progression associated with severe hematological disease occurred on day 33 after admission. Spontaneous abortion occurred at 21-22 weeks of gestation. Labor and prolongation of pregnancy occurred in 42 (63.6\%) and 20 (30.3\%) cases respectively, and spontaneous abortions occurred in four cases (6.1\%) out of 66 . Deliveries were performed in 42 women, of those eight cases of preterm labor (19\%), and 34 cases of labor at term (81\%). Caesarean section was performed in 17 patients (40.5\%), and vacuum extraction vaginal delivery due to fetal distress was performed in two patients (4.8\%); normal vaginal delivery occurred in 23 patients (54.7\%). The average birth weight was $3,283 \pm 477 \mathrm{~g}$, and the average birth length was $52 \pm 2.75 \mathrm{~cm}$. The newborns were assigned Apgar score at one minute $(7.8 \pm 0.6)$ and five minutes $(8.7 \pm 0.5)$ of age. No cases of COVID-19 in newborn infants were registered. The infants were isolated from their mothers immediately after birth, until their 

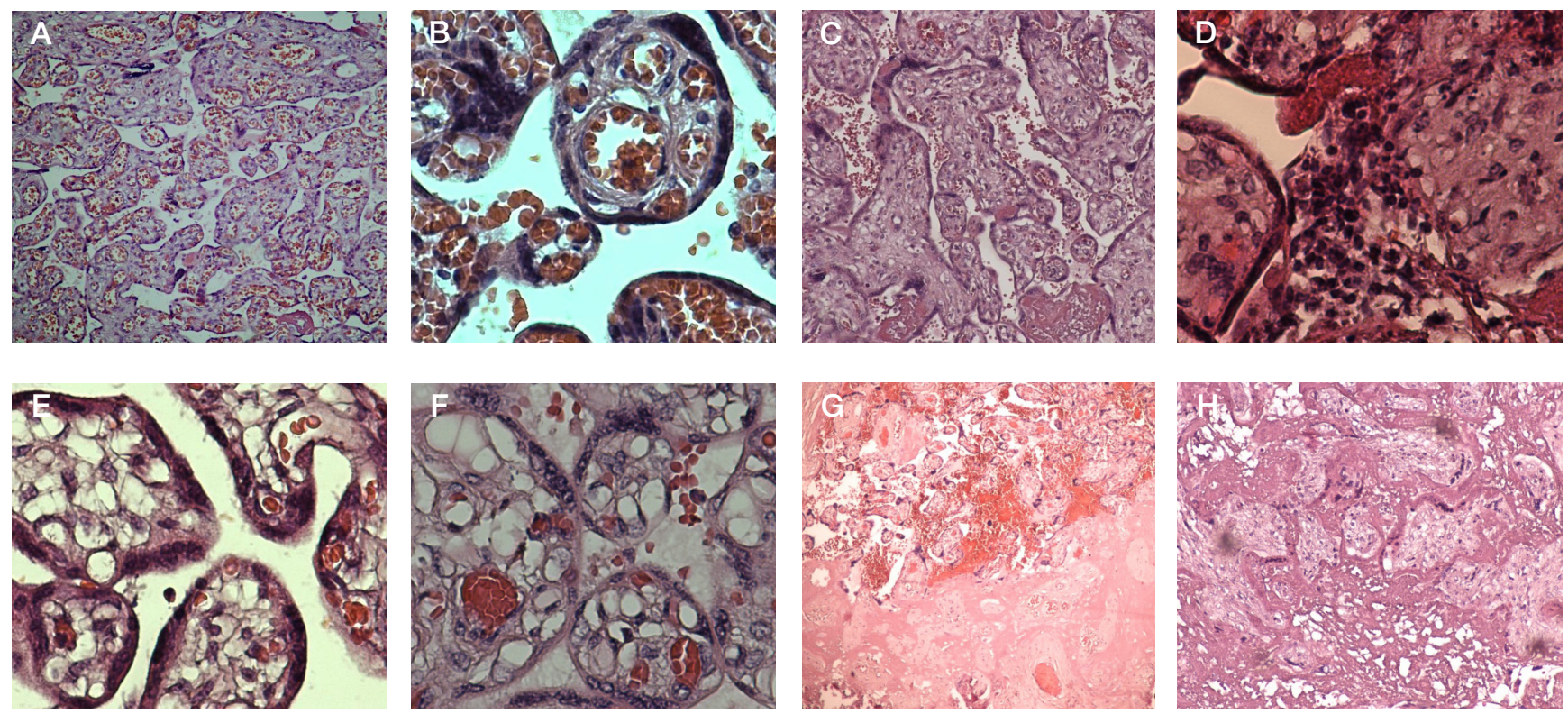

Fig. 1. Histological changes in placental villous trees of women with novel coronavirus infection. A. Placenta of women with uncomplicated pregnancies, one terminal villus contains 3-7 vessels; $\times 40$. B. Placenta of women with uncomplicated pregnancies, one terminal villus contains 3-7 vessels 3-7; $\times 400$. C. Placenta of patients with COVID-19; increased fibrinoid deposition; $\times 100$. D. Placenta of patients with COVID-19; focal accumulations of inflammatory cells (macrophages, lymphocytes with a dash of plasmocytes and sporadic neutrophils); $\times 400$. E. Placenta of patients with COVID-19; angiogenesis with predominant vascular branching: capillary number increase in one villus to more than 10 together with blood vessel diameter reduction; intact syncytiotrophoblast membranes attract attention. F. Placenta of patients with COVID-19; angiogenesis with predominant vascular branching: capillary number increase in one villus to more than 10 together with blood vessel diameter reduction. G. Placenta of patients with COVID-19; multiple infarction and hemorrhages in placental samples obtained from women with COVID-19. H. Placenta of patients with COVID-19

mothers tested negative twice for SARS-CoV-2. After getting a negative PCR test result the women resumed breastfeeding. All newborn infants were tested for SARS-CoV-2 immediately after birth, as well as at three and 10 days of age. All newborns tested negative for the virus. This could indicate lack of vertical transmission of the infection.

Placental tissue samples obtained from 42 patients who delivered in the red zone, one dead patient and 40 healthy women of the comparison group were sent to the Anatomical Pathology Department for further histological assessment and $\mathrm{IHC}$ analysis. Histological assessment revealed fewer than expected inflammatory conditions of placenta (umbilical cord, fetal membranes, and villous tree) in patients with COVID-19 (less than 10\%). Focal forms of villitis prevailed ( $>3$ affected fields of view out of 10 viewed at 200x magnification), which could be detected only when using $\mathrm{HC}$ staining with antibodies to CD4 (marker of lymphocytes and macrophages) (Fig. 1A-F and 2A-D). In-depth analysis of complex placental changes in the index group patients revealed significant differences $(p<0.05)$, such as predominance of terminal villi hypercapillarization (moderate and severe degree) or pathological immaturity of the villous tree (see Fig. 1A-F). In patients with COVID-19, histological features of the villous tree corresponded to moderate and severe branching angiogenesis (angiogenesis with predominant vascular branching) (score 23 and 32, scales by Berniske, Kaufman, 2006). This indicated the compensatory mechanisms involvement and was more often characteristic of intrauterine hypoxia. The placental villous infarction rate was significantly higher in patients with novel coronavirus infection; it was mainly associated with severe forms of the disease $(p<0.05)$ (see Fig. 1A-F). The rate of intravillous hemorrhage and blood clots in the lumen of blood vessels showed the upward trend (see Fig. 1A-F). In the placenta of the woman with leukemia (the fatal case), up to $90 \%$ of the villous tree was affected, surrounded by infarcted fields, multiple hemorrhages and hematomas (subamniotic, intervillous, retrochorial), and massive fibrinoid deposition making it possible to distinguish only a few villi, some of which were dystrophic (see Fig. 1A-F). At the same time, in patients with COVID-19 who gave birth to healthy babies, the analysis of placental villous tree and the degree of villous syncytiotrophoblast damage revealed intact syncytiotrophoblast membranes, and no cells sloughed off the surface of the villi. In our opinion, the key consideration is the fact that in women with COVID-19 the trophoblast damage degree was less than $10 \%$, i. e. it could be considered the normal value [7]; when entering the mother's bloodstream, the destroyed trophoblast compartments did not trigger maternal systemic inflammatory response observed in preeclampsia. During evaluation of $\mathrm{HC}$ study results with the use of primary antibody to SARS-CoV-2 N-protein, lack of staining in most placental villi in women with mild forms of the disease drew the attention. In women with moderate and severe infection, the following features were detected: focal staining of individual syncytiotrophoblast villi membrane and cytoplasm, syncytial knots, small areas of the basement membrane, endothelium of individual villous vessels, and macrophages (Fig. 3A-F). No viral particles were detected in fetal membranes and umbilical cord. On the contrary, in patient with leukemia (the fatal case), individual villi positively stained with antibody to virus could be distinguished among the infracted fields and hemorrhages (Fig. 3; dark areas). Positively stained areas matched the villous syncytiotrophoblast contour; some villi with evident dystrophic changes were embedded in fibrinoid deposition (see Fig. 3A-F). Thus, the function of fibrinoid produced primarily of coagulated plasma proteins in the sites of villous tree damage is to separate maternal and fetal blood circulation in case of placental damage; when the viral particles enter the intervillous space, it seeks to localize and inactivate viral particles in order to prevent them from entering the fetal bloodstream. There were no signs of vasculitis and perivasculitis in blood vessels of patients with COVID-19 who gave birth to healthy babies, which was in contradiction to data on lung injury and damage to other organs resulting from granulomatous inflammation reported by a number of authors $[8,9]$. In the index group, 

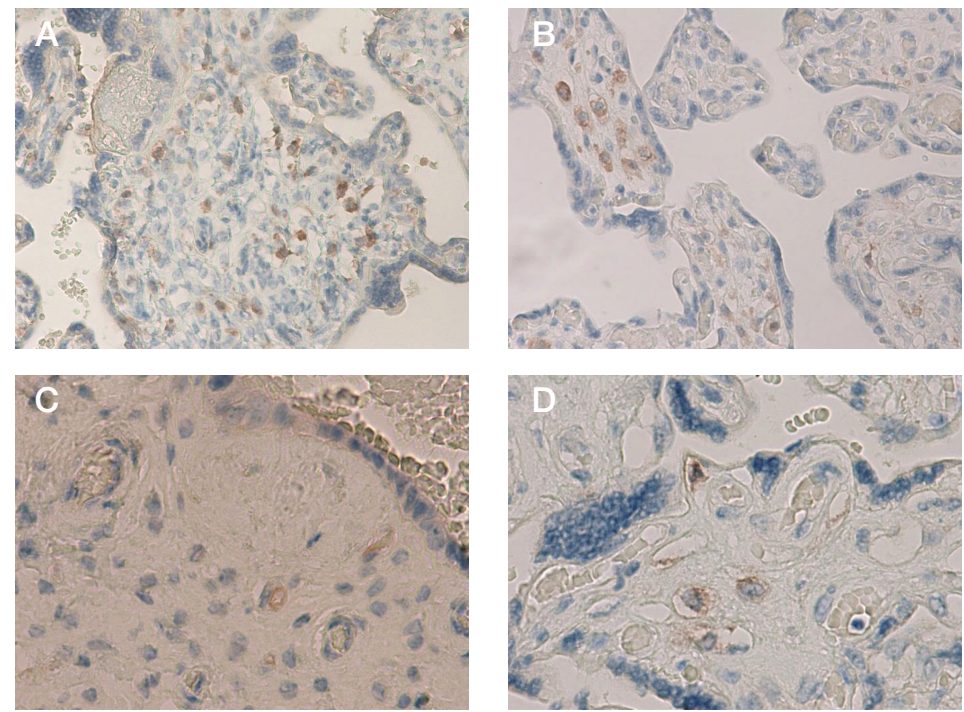

Fig. 2. CD4 expression in placental tissue in patients with COVID-19 and comparison group. A. Focal increase in the number of CD4 $4^{+}$macrophages and lymphocytes in the villous stroma in patients with COVID-19; $\times 200$. B. Focal increase in the number of CD4+ macrophages and lymphocytes in the villous stroma in patients with COVID-19; $\times 200$. C. Focal increase in the number of CD4+ macrophages and lymphocytes in the villous stroma in patients with COVID-19; $\times 400$. D. Macrophages $\mathrm{CD} 4{ }^{+}$in the villous stroma in women with uncomplicated pregnancy; $\times 400$

IHC staining with primary antibody to TNF $\alpha$ revealed moderate staining of cytotrophoblast and syncytiotrophoblast membrane and cytoplasm, macrophage and lymphocyte cytoplasm, epithelium, as well as syncytial knots, functioning as the zones of trophiblast proliferation, extravillous cytotrophoblast and decidual cells. Prominent staining was observed in the perivillous fibrinoid (Fig. 4A-D). This demonstrated elevated plasma levels of proinflammatory markers compared to placenta. Assessment of IL8 revealed more prominent staining in the listed above structures, primarily in syncytiotrophoblast (Fig. 5A-F). As is known, syncytiotrophoblast forms the placental barrier, which functions as the main barrier for the virus. Downregulation of proinflammatory cytokine IL4 expression was observed in placenta of the index group patients with COVID-19 (Fig. 6A-D).
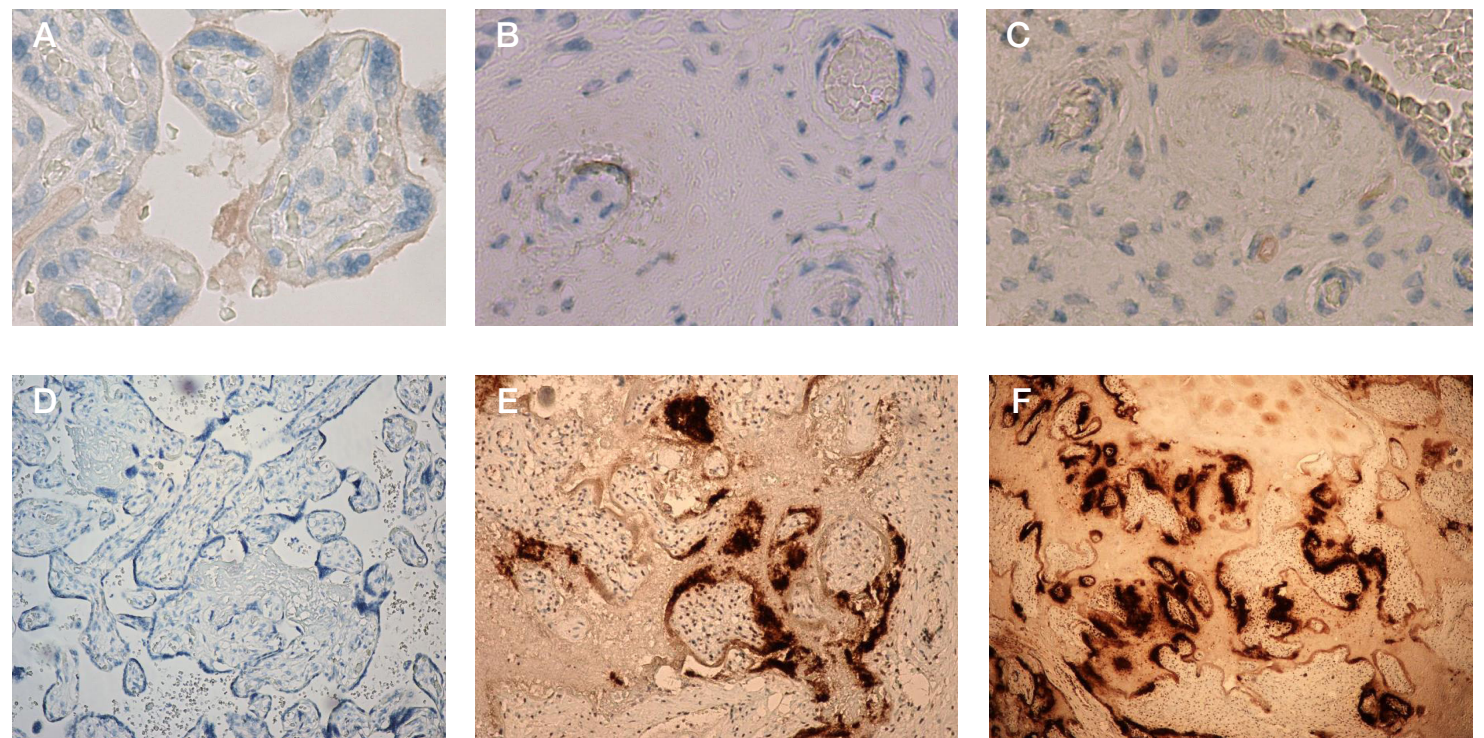

Fig. 3. Placental tissue immunohistochemical analysis using primary antibody to SARS-COV-2. A. Weak syncytiotrophoblast membrane and fibrinoid deposits staining in placental tissue of patients with COVID-19, intact syncytiotrophoblast membrane attracts attention; $\times 200$. B. Weak focal staining of endothelium in individual villous vessels; $\times 400$. C. Weak syncytiotrophoblast membrane and fibrinoid deposits staining in placental tissue of patients with COVID-19, intact syncytiotrophoblast membrane attracts attention, $\times 200$; weak focal staining of endothelium in individual villous vessels, $\times 400$. D. Negative staining. Placenta of women with no history of COVID-19; $\times 100$. E. Prominent positive staining of viral particle accumulations around the perimeter of dystrophic villus. Placenta of a woman with acute leukemia, who died from COVID-19. The fetus died in utero from placental insufficiency at 20 weeks of gestation. Stained inflammatory cells are visible: lymphocytes, macrophages; $\times 100$. F. Prominent positive staining of viral particle accumulations around the perimeter of dystrophic villus. Placenta of a woman with acute leukemia, who died from COVID-19. The fetus died in utero at 20 weeks of gestation from placental insufficiency; $\times 40$ 

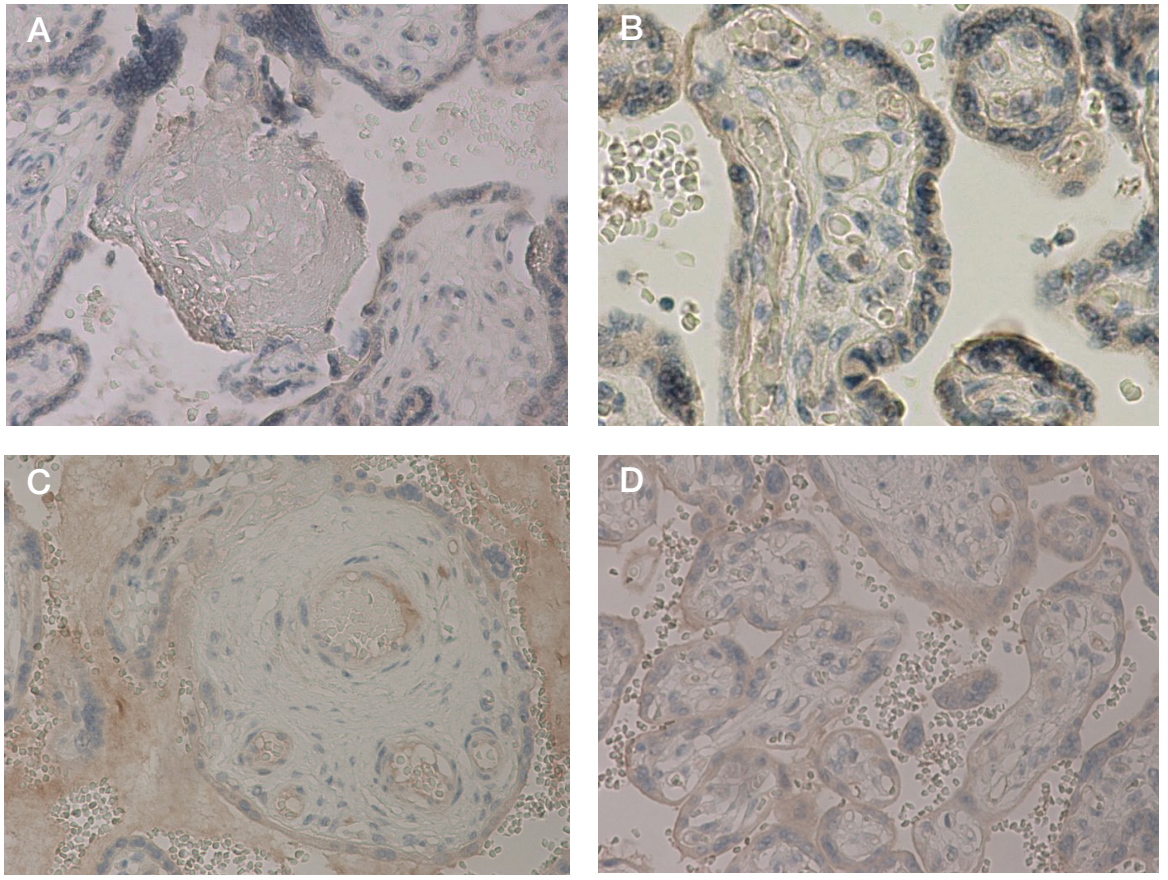

Fig. 4. TNF $\alpha$ expression in placental tissue in patients with COVID-19 and comparison group. A. TNF $\alpha$ expression in placental structures of women with uncomplicated pregnancy, weak staining of syncytiotrophoblast membrane and cytoplasm, as well as of vascular endothelium; no staining of fibrinoid deposits; $\times 100$. B. TNF $\alpha$ expression in placental structures of women with uncomplicated pregnancy, weak staining of syncytiotrophoblast membrane and cytoplasm, as well as of vascular endothelium; no staining of fibrinoid deposits; $\times 200$. C. TNF $\alpha$ expression in placental structures of women with COVID-19. Weak staining of vascular endothelium; positively stained fibrinoid deposits; $\times 200$. D. TNF $\alpha$ expression in placental structures of women with COVID-19. Weak staining of vascular endothelium (Fig. C); as well as of syncytiotrophoblast membrane and cytoplasm, and syncytial knots (Fig. D); positively stained fibrinoid deposits (Fig. C); ×200

observed in placental structures of patients with moderate and severe COVID-19.

An important reason for impairment of umbilical blood flow is blood clot and sludge formation in the umbilical cord and chorionic blood vessels, also referred to as fetal thrombotic vasculopathy $[10,11]$. Hypercapillarization of terminal villi is a compensatory mechanism for hypoxia, which is attributable to elevated level of angiogenic factors promoting growth of new blood vessels, such as VEGF. In case of prominent terminal villi hypercapillarization (32-33 points in accordance with the scale) [12] rearrangement occurs during angiogenesis resulting in slowing down in microcirculation and fetoplacental blood flow. Therefore, platelet aggregation in the capillary lumen increases, and microthrombi are formed. Upregulation of these processes
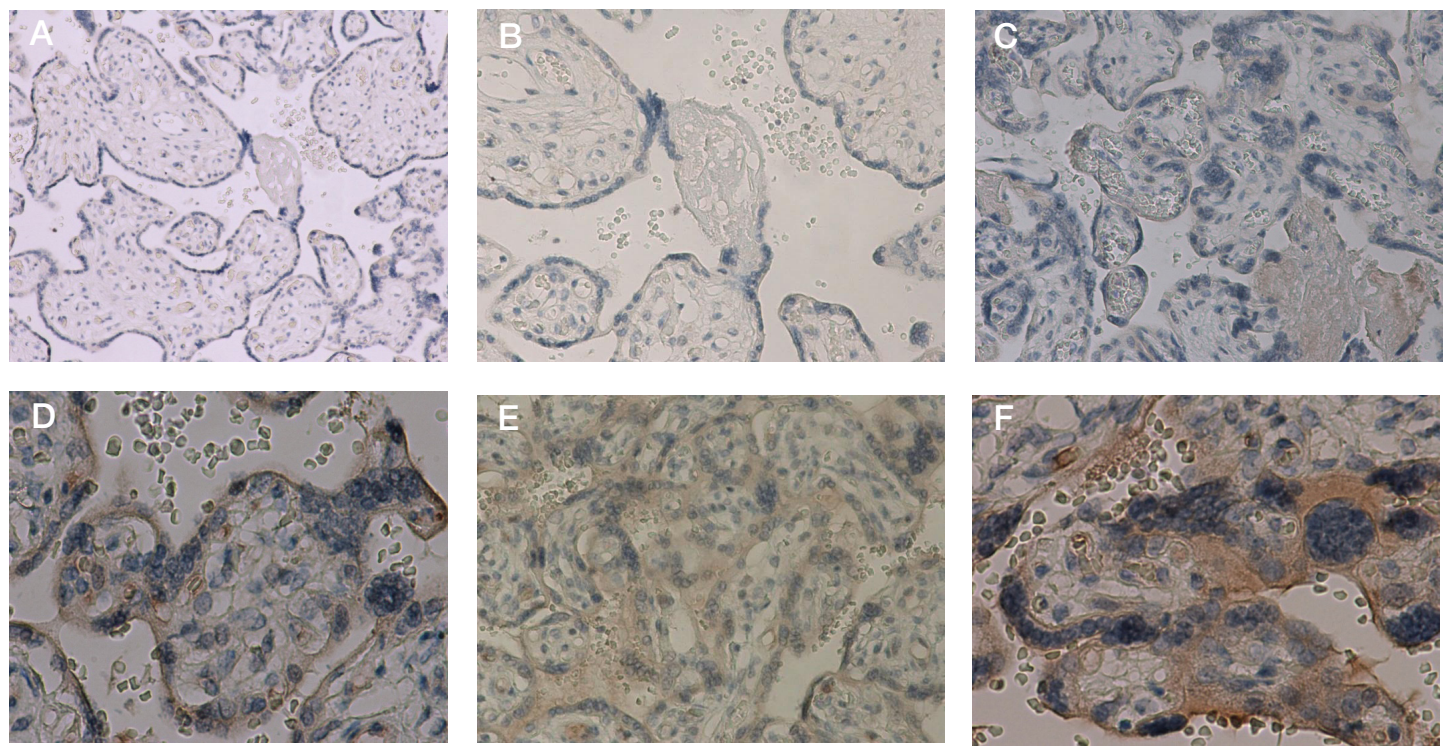

Fig. 5. IL8 expression in placental tissue in patients with COVID-19 and comparison group. A. IL8 expression in placental structures of women with uncomplicated pregnancy, weak staining of syncytiotrophoblast membrane and cytoplasm, as well as of vascular endothelium; no staining of fibrinoid deposits; $\times 100$. B. IL 8 expression in placental structures of women with uncomplicated pregnancy, weak staining of syncytiotrophoblast membrane and cytoplasm, as well as of vascular endothelium; no staining of fibrinoid deposits; $\times 200$. C. IL8 expression in placental structures of women with COVID-19; IL8 expression in patients with mild forms of the disease: weak staining predominantly in the syncytiotrophoblast membrane and cytoplasm; weak staining of fibrinoid deposits; $\times 100$. D. IL8 expression in placental structures of women with COVID-19; IL8 expression in patients with moderate forms of the disease: more prominent staining of placental structures, mostly in the syncytiotrophoblast; intensively stained fibrinoid deposits; some villi are embedded in fibrinoid deposits; $\times 400$. E. IL8 expression in placental structures of women with COVID-19; IL8 expression in patients with moderate forms of the disease: more prominent staining of placental structures, mostly in the syncytiotrophoblast; intensively stained fibrinoid deposits; some villi are embedded in fibrinoid deposits; $\times 200$. F. IL8 expression in patients with moderate forms of the disease: more prominent staining of placental structures, mostly in the syncytiotrophoblast; intensively stained fibrinoid deposits; some villi are embedded in fibrinoid deposits 

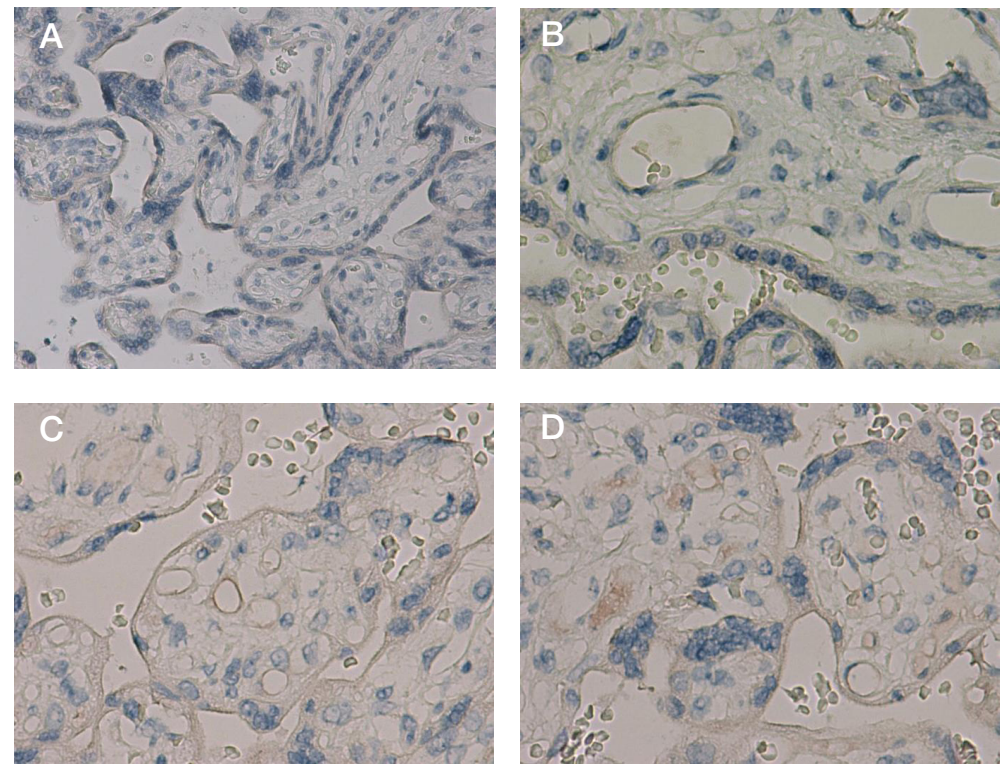

Fig. 6. Expression of proinflammatory mediator IL4 in placental villi in patients with COVID-19 and comparison group. A. IL4 expression in placental structures of women with uncomplicated pregnancy; weak staining of syncytiotrophoblast and villous vessel endothelium; $\times 100$. B. IL 4 expression in placental structures of women with uncomplicated pregnancy; weak staining of syncytiotrophoblast and villous vessel endothelium; $\times 400$. C. IL 4 expression in placental structures of women with COVID-19: decreased staining is visible. D. IL4 expression in placental structures of women with COVID-19: decreased staining is visible

results in focal villous stromal fibrosis; changes initially focused on hypoxia negative impact compensation facilitate gradual transition to decompensation. In our study, the frequency of moderate and severe terminal membrane hypercapillarization in the index group was significantly higher than in comparison group. The study results showed higher proportion of infarctions, as well as the presence of chorionic vessels thrombosis, and intervillous and subamniotic hematomas in the index group compared to controls. In addition to mechanical factors, blood clot formation is caused by violation of blood rheological properties (slowdown in blood flow, decreased diameter of blood vessels), and coagulation system disorders. These factors are characteristic of novel coronavirus infection. Morphological features of placenta suggested that acute fetal hypoxia during labor occurred in cases of chronic fetal hypoxia in the mother-placenta-fetus system or any other disturbing factor influence during pregnancy $[13,14]$. As a result, the villous tree rearrangement occurred, and the subclinical placental insufficiency developed. The influence of additional triggers during labor (uterine contractile activity, umbilical cord compression, etc.) resulted in decompensation with clinical manifestations of acute fetal hypoxia.

Evaluation of $\mathrm{IHC}$ analysis results revealed no significant increase in the proinflammatory marker levels against the background of decreased inti-inflammatory marker levels in patients with moderate and severe infection.

\section{CONCLUSIONS}

In the recent decade, advances in immunology and broader understanding of innate and acquired immunity mechanism resulted in growing interest in studying the individual differences of immune response associated with infectious inflammatory diseases. Studying the immune response differences in individuals with predominant Th1 or Th2 response, which largely determines the clinical, morphological and immunological features of the inflammatory response, is the most productive. Thus, pregnancy may be considered as a factor contributing to more favorable course of COVID-19. The reported higher proportion of hypoxia during labor may be associated with coagulation system disorders and result from higher proportion of chorionic blood vessel thromboses, as well as from intervillous, subamniotic, retrochorial hematomas, and villous tree infarctions. Placenta functions as an "airbag" for the fetus, and the intact placental barrier protects the fetus against COVID-19. However, under certain conditions, in case of "broken" placental barrier the novel coronavirus infection may be dangerous for the fetus: the infection can induce the cytokine-storm-type changes. Placenta minimizes the burden on the fetus. The vast majority of babies are born healthy, and the placental levels of proinflammatory cytokines are comparable with those in comparison group. Intact placenta and placental barrier protect the unborn baby against infections, and the impact on the child's development is minimal. Taking into account higher proportion of hypoxia occurring during labor in infants born from mothers with COVID-19, the obstetrical tactics for mothers with COVID-19 should be decided individually based on the risk factors; continuous cardiotocography should be used during labor. It may be appropriate to conduct $\mathrm{HC}$ analysis of placenta in puerperant women with suspected novel coronavirus infection COVID-19 using primary antibodies to Sars-CoV-2 in order to fine-tune the tactics of neonatal management and to predict possible neonatal complications.

\section{References}

1. Zhu H, Wang L, Fang C, Peng S, Zhang L, Chang G, et al. Clinica analysis of 10 neonates born to mothers with 2019-nCoV pneumonia. Transl Pediatr. 2020; 9 (1): 51-60. DOI: 10.21037/tp.2020.02.06.

2. Liu Y, Chen H, Tang K, Guo Y. Clinical manifestations and outcome of SARS-CoV-2 infection during pregnancy. J Infect. 2020; DOI: 10.1016/j.jinf.2020.02.028. 
3. Varga Z, Flammer AJ, Steiger P, Haberecker M, Andermatt R, Zinkernagel AS, et al. Endothelial cell infection and endotheliitis in COVID-19. Lancet. 2020; 395 (10234): 1417-8. DOI: 10.1016/ S0140-6736(20)30937-5.

4. Dashraath P, Wong JLJ, Lim MXK, Lim LM, Li S, Biswas A, et al. Coronavirus disease 2019 (COVID-19) pandemic and pregnancy. Am J Obstet Gynecol. 2020; 222 (6): 521-31. DOI: 10.1016/j. ajog.2020.03.021.

5. Schwartz DA, Graham AL. Potential maternal and infant outcomes from coronavirus 2019-NCOV (SARS-CoV-2) infecting pregnant women: Lessons from SARS, MERS, and other human coronavirus infections. Viruses. 2020; 12 (2): 194. DOI: 10.3390/v12020194.

6. Chen H, Guo J, Wang C, Luo F, Yu X, Zhang W, et al. Clinica characteristics and intrauterine vertical transmission potential of COVID-19 infection in nine pregnant women: a retrospective review of medical records. Lancet. 2020; 395 (10226): 809-15. DOI: 10.1016/S0140-6736(20)30360-3.

7. Baev OR, Karapetyan AO, Nizyaeva NV, Sadekova AA, Krasny AM. Soderzhanie vnekletochnoj DNK ploda $v$ materinskoj krovi i jekspressija DNK-raspoznajushhih ZBP-1 receptorov $v$ strukturah placenty pri prejeklampsii i prezhdevremennyh rodah. 2019; 3: 179-84. Russian.

8. Becker RC, et al. COVID-19-associated vasculitis and vasculopathy. Journal of thrombosis and thrombolysis, 2020; 50 (3): 499-511. Available from: https://doi.org/10.1007/s11239-020-02230-4.

\section{Литература}

1. Zhu H, Wang L, Fang C, Peng S, Zhang L, Chang G, et al. Clinical analysis of 10 neonates born to mothers with 2019-nCoV pneumonia. Transl Pediatr. 2020; 9 (1): 51-60. DOI: 10.21037/ tp.2020.02.06.

2. Liu Y, Chen H, Tang K, Guo Y. Clinical manifestations and outcome of SARS-CoV-2 infection during pregnancy. J Infect. 2020; DOI: 10.1016/j.jinf.2020.02.028.

3. Varga Z, Flammer AJ, Steiger P, Haberecker M, Andermatt R, Zinkernagel AS, et al. Endothelial cell infection and endotheliitis in COVID-19. Lancet. 2020; 395 (10234): 1417-8. DOI: 10.1016/ S0140-6736(20)30937-5.

4. Dashraath P, Wong JLJ, Lim MXK, Lim LM, Li S, Biswas A, et al. Coronavirus disease 2019 (COVID-19) pandemic and pregnancy. Am J Obstet Gynecol. 2020; 222 (6): 521-31. DOI: 10.1016/j. ajog.2020.03.021.

5. Schwartz DA, Graham AL. Potential maternal and infant outcomes from coronavirus 2019-NCOV (SARS-CoV-2) infecting pregnant women: Lessons from SARS, MERS, and other human coronavirus infections. Viruses. 2020; 12 (2): 194. DOI: 10.3390/ v12020194.

6. Chen H, Guo J, Wang C, Luo F, Yu X, Zhang W, et al. Clinical characteristics and intrauterine vertical transmission potential of COVID-19 infection in nine pregnant women: a retrospective review of medical records. Lancet. 2020; 395 (10226): 809-15. DOI: 10.1016/S0140-6736(20)30360-3.

7. Баев О. Р, Карапетян А. О., Низяева Н. В., Садекова А. А. Красный А. М. Содержание внеклеточной ДНК плода в материнской крови и экспрессия ДНК-распознающих ZВР1 рецепторов в структурах плаценты при преэклампсии и
9. Hosier H, Farhadian SF, et al. SARS-CoV-2 infection of the placenta. 2020; J Clin Invest. 2020; 130 (9): 4947-53. Available from: https://doi.org/10.1172/JCl139569.

10. Issa $\mathrm{AH}$, Jaber BMS. Evaluation of predictive ability for the indicator of natal cord coils of the pregnant women. World $J$ Pharm Res. 2019; 8 (5): 197-208.

11. Bitsadze VO, Makatsariya AD, Hizroeva DH, Makatsariya NA, Yashenina EV, Kazakova LA. Thrombophilia as the most important link of the pathogenesis of pregnancy complications. Practical medicine. 2012; 9 (65): 24-31. Russian.

12. Shchyogolev Al, Dubova EA, Pavlov KA, Lyapin VM, Kulikova GV, Shmakov RG. Morphometric characteristics of terminal villi of the placenta in preeclampsia. Bulletin of Experimental Biology and Medicine. 2013; 154 (1): 92-95.

13. Nizyaeva NV, Prihodko AM, Evgrafova AV, Tysyachny OV, Baev OR. Kliniko-morfologicheskie osobennosti placenty pri ostroj vnutriutrobnoj gipoksii v rodah. Akusherstvo i ginekologija. 2019; 12: 96-104. Dostupno po ssylke: https://dx.doi.org/10.18565/ aig.2019.12.96-104. Russian.

14. Hcini N, Maamri F, Picone O, Carod JF, Lambert V, Mathieu M, et al. Maternal, fetal and neonatal outcomes of large series of SARSCoV-2 positive pregnancies in peripartum period: A single-center prospective comparative study. European journal of obstetrics, gynecology, and reproductive biology. 2020; 257: 11-18. Available from: https://doi.org/10.1016/j.ejogrb.2020.11.068.

преждевременных родах. 2019; 3: 179-84.

8. Becker RC, et al. COVID-19-associated vasculitis and vasculopathy. Journal of thrombosis and thrombolysis, 2020; 50 (3): 499-511. Available from: https://doi.org/10.1007/s11239-020-02230-4.

9. Hosier H, Farhadian SF, et al. SARS-CoV-2 infection of the placenta. 2020; J Clin Invest. 2020; 130 (9): 4947-53. Available from: https://doi.org/10.1172/JCl139569.

10. Issa $A H$, Jaber BMS. Evaluation of predictive ability for the indicator of natal cord coils of the pregnant women. World $\mathrm{J}$ Pharm Res. 2019; 8 (5): 197-208.

11. Бицадзе В. О., Макацария А. Д, Хизроева Д. Х., Макацария Н. А., Яшенина Е. В., Казакова Л. А. Тромбосилия как важнейшее звено патогенеза осложнений беременности. Практическая медицина. 2012; 9 (65): 24-31.

12. Shchyogolev Al, Dubova EA, Pavlov KA, Lyapin VM, Kulikova GV, Shmakov RG. Morphometric characteristics of terminal villi of the placenta in preeclampsia. Bulletin of Experimental Biology and Medicine. 2013; 154 (1): 92-95.

13. Низяева Н. В., Приходько А. М., Евграфова А. В., Тысячный О. В., Баев О. Р. Клинико-морфологические особенности плаценты при острой внутриутробной гипоксии в родах. Акушерство и гинекология. 2019; 12: 9-104. Доступно по ссылке: https:// dx.doi.org/10.18565/aig.2019.12.96-104.

14. Hcini N, Maamri F, Picone O, Carod JF, Lambert V, Mathieu M, et al. Maternal, fetal and neonatal outcomes of large series of SARSCoV-2 positive pregnancies in peripartum period: A single-center prospective comparative study. European journal of obstetrics, gynecology, and reproductive biology. 2020; 257: 11-18. Available from: https://doi.org/10.1016/j.ejogrb.2020.11.068. 